\title{
THE CROP-LIVESTOCK INTEGRATION INNOVATION USING PALM OIL BY- PRODUCTS TECHNOLOGY TO SUPPORT BEEF CATTLE PRODUCTION IN WEST SUMATRA.
}

\author{
Abdullah M Bamualim ${ }^{1}$, Fuad Madarisa ${ }^{2}$, Yolas Pendra $^{3}$, Edy Mawardi $^{1}$ and Asmak $^{1}$ \\ ${ }^{1}$ West Sumatra's Agricultural Technology Assessment Institute, Sukarami-Solok \\ ${ }^{2}$ Animal Husbandry Faculty, the Andalas University Padang and \\ ${ }^{3}$ West Sumatra's Animal Production and Veterinary Services Padang.
}

*Corresponding author : fmadarisa@gmail.com

Received : 16 Mei 2015

Accepted : 2 Desember 2015

\begin{abstract}
A study has been conducted on the crop-livestock integration innovation using palm oil by-products technology to support beef cattle production in 2014. The collected data consisted of (i) Socio-economic aspects, (ii) The body weight gain of cattle, and (iii) Palm oil production. These data were taken from Sri Langgeng farmers group (13 respondents) in Dharmasraya district and Tanjung Keramat farmers group (10 respondents) in West Pasaman district. The results of the socio economic aspects showed; the average age of farmers was 39 years old, owned palm oil plantation of 2,2 and, 4,1 ha, and owned of 4.2 and 6.2 head of cattle in Tanjung Keramat and Sri Langgeng respectively. The average monthly income was $\mathrm{Rp} 1.63$ million and about $\mathrm{Rp} 1.05$ million derived from livestock contribution in Tanjung Keramat, and Rp 1.65 million and about Rp 1.71 million derived from livestock contribution in Sri Langgeng. Feeding a supplement of palm oil by-products increased cattle growth by about 0.14 and $0.09 \mathrm{~kg} / \mathrm{head} /$ day at Sri Langgeng and Tanjung Keramat respectively. In contrast, the animals in a control treatment experienced body weight losses of -0.17 and $-0.11 \mathrm{~kg} / \mathrm{head} /$ day. The application of organic fertilizer from cattle manure, above the inorganic fertilizer, increased the palm oil fruit by $39.4 \%$ and $48.4 \%$. The research proved that there is an opportunity to accelerate the adoption process of crop-livestock integration in palm oil plantation areas in West Sumatra.
\end{abstract}

Keywords: crop-livestock integration, palm oil by-products technology.

\section{INTRODUCTION}

In general, there is an extensive system of keeping beef cattle in West Sumatra. Due to the use of native grasses and small amounts of feed additives, beef cattle productivity is relatively low. The avilability of continuously high quality beef cattle feed is a constraint to increasing productivity.

One of the solutions to provide high quality feeding is the use of agricultural by-products as an alternative source. This option is worth considering when anticipating the shortage of natural grass supply due to climate pressure and land use conversion. Agricultural by-products are not yet optimally utilized. The palm oil plantation, with diverse products and by-products, offers opportunities to increase animal production. For example, there are 457,000 ha palm oil plantations across West Sumatra, of which 175,000 ha have been producing crude palm oil.

Some of palm the plant and palm oil by-products consist of palm oil fronds (leaves and petioles), solid, and palm kernel cake. While the fronds are the biggest volume and component of palm byproducts as grass replacements for beef cattle feed, solid or palm oil mill affluent produces crude palm oil which contains $13 \%$ of protein. Palm kernel cake (PKC) which are predominantly exported abroad, contains $15-17 \%$ protein for a competitive price.

The potential of palm by-products as a source of beef cattle feeding are 1.07 million tons leaf stalk which could provide feeding for 595,000 head of cattle. PKC is also available at 45,000 tons to feed 63,000 head of cattle. PKC could also feed 25,000 head of cattle in West Sumatra (Buharman, 2011). In fact, Bamualim et al. (2012) found at three districts with dominant palm plantation location that nearly 
$70 \%$ of cattlemen are yet to utilize palm by-products as a source of cattle feed. Farmers as well as cattlemen primarily use fresh natural grass to feed their cattle as a main feed supply. This is miss opportunity, where farmers are not using readily by-products to feed cattle.

Mathius et al, (2004) showed that cattle fed by palm oil by-products responded by $0.338 \mathrm{~kg}$ of average daily gained (ADG) weight. For example, beef cattle with a feeed composition consisting palm oil fronds (55\%), native grass (30\%) and solid performed better. Cattle increased body weight by 0.23 $\mathrm{kg} /$ day with a quantity of feed consumption of $8.85 \mathrm{~kg} /$ head/day (Azmi and Gunawan, 2005).

Elisabeth et al. (2003) have proved that using palm oil fronds, solid and PKC for cattle feeding increased body weight. The research used two treatments; (i) feed composition consisting of palm oil fronds $(60 \%)$, solid (18\%), PKC (18\%), and rice bran (4\%). (ii) feed composition consisting of palm oil fronds $(30 \%)$, solid $(40 \%)$, PKC (26\%), and rice bran (4\%). In fact, the first treatment was more efficient compared to the second treatment with ADG $0.5 \mathrm{~kg} / \mathrm{head} /$ day for local cattle, consuming $8.6 \mathrm{~kg}$ daily dry materials and a feed conversion of 13.9 for 6 weeks of the keeping period.

In 2011, BPTP (West Sumatra's Agricultural Technology Assessment Institute), at Sukarami showed PKC supplements for beef cattle at Pasaman Barat district (Wirdahayati et al, 2011) and Dharmasraya district (Bamualim et al, 2011) resulted increased ADG and cow reproductive indicators also responded. The research produced feed technology for beef cattle by using palm oil by-products supporting the West Sumatra program to increase the acceleration of both cattle population and body weight.

Keeping cattle has the potential for supporting palm oil farmers by producing organic fertilizer from cattle dung. The use of organic fertilizers could increase palm oil fruit products and reduce the chemical fertilizer input and therefore reduce cost.

Hence, this collaborative innovative research on using palm oil by-products technology was conducted. The research involved synergetic interactions among the BPTP stakeholders, both provincial and district government institutions, Animal Husbandry Faculty of Andalas University, and farmers groups to accelarate adoption of the crop-livestock integration innovation using palm oil by-products technology to support beef cattle production in West Sumatera.

The research objectives were aimed at (1) increasing the cattle production (body weight and ferquency of pregnancy); (2) increasing palm fruits using organic fertilizer of cattle manure; (3) increasing efficiency of feed consumption using locally potential resources.

\section{Coordination with related Institutions}

Procedure of transparent coordination was used to select both locations and farmer group candidates in order to achieve research objectives as well as intended outputs. Farmer groups were selected that intended to apply palm oil by-products innovation technology and were commited to work together with the research team.

\section{Baseline Socio Economic Survey}

A baseline study was conducted on beef cattle businesses surrounding the palm plantation locations. The survey was designed to gather information on the type of systems of keeping cattle, number of cattle, feed resources, cattle production, farmer income, and existing palm oil by-products usage.

\section{Usage offeeding from palm oil by-product technology:}

This activity consisted of providing palm oil fronds, solid and PKC to feed both beef and productive cattle in a communal pen. At each location at least 20 head of cattle were used, mostly consisting of Bali cows with two treatments;

a. Controlled treatment, where cattle fed grass and legume only.

b. Cattle feed palm oil by-products with feed formulation as shown in Table 1 . 
The second treatment required a four month period at a farmer location. In West Pasaman, there is a

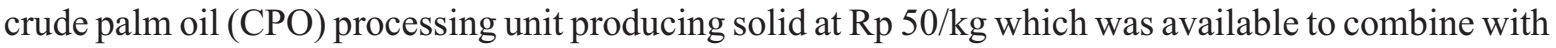
silage of palm oil fronds and PKC as the best choice. But, there was a lack of solid supply due to the problem of palm oil processing unit, therefore solid was not used at this treatment. In Dharmasraya district there was no solid available, so the research could not use it.

Table 1. Composition of BeefCattle Feeding Using Palm by-Products.

\begin{tabular}{llccc}
\hline No & \multicolumn{1}{c}{ Feed Composition } & \multicolumn{3}{c}{ Percentage of Dry Feed (\%) } \\
& & Control & \multicolumn{2}{c}{ Palm Basis } \\
& & - & 60 & 60 \\
\hline 1 & Silage of leaf stalk & $80-90$ & - & - \\
2 & Grass & $10-20$ & - & - \\
3 & Legume & - & 25 & 25 \\
4 & PKC & - & 5 & 0 \\
5 & Solid & - & 5 & 10 \\
6 & Molasses & - & 5 & 5 \\
7 & Rice bran & & Dest Pasaman & Dharmasraya \\
\hline
\end{tabular}

Procedure to produce silage of palm oil fronds was done by adding rice bran $(30 \mathrm{~kg})$, molasses $(30 \mathrm{~kg})$ and urea $(2.5 \mathrm{~kg})$. Some indicators were used as parameters such as; feed consumption, ADG and pregnancy performance.

\section{Organic fertilizer to palm oil plantation}

To identify the effect of using organic fertilizer from cattle manure to palm oil fruit production, two treatments were conducted in the field.

a. Controlled treatment for 10 units of producing palm trees with usual inorganic fertilizer according to the normal dosage.

b. Treatment for 10 producing palm trees with inorganic fertilizer as well as organic fertilizer fitted around the palm oil trees $(50 \mathrm{~kg} / \mathrm{palm}$ unit).

The indicators identified included two aspects; the quantity of palm oil fruit and a financial analysis of using fertilizers.

\section{RESULTS AND DISCUSSION}

Results and discussion were in accord with the four step series of research procedures.

Coordination and selection of location

Coordination with district extension services in selecting the activities location.

The coordination approach was conducted at each district through the Animal and Fishery Extension Services at Dharmasraya and Food, Horticulture and Animal Extension Services at West Pasaman respectively. Several substantial aspects were discussed including action research planning procedures of selection and evaluation of the locations.

\section{Selecting groups and location}

Groups and locations were selected based on the following principles:

a. Increase of local cattle productivity using feed innovation of palm oil by-products.

b. Usage of organic fertilizer from cattle manure to palm oil trees.

c. Accelerating the improvement of farmers' income by integrating cattle within palm plantations.

d. The condition of the farmers' groups candidates were identified by the following standards; 
e. Farmers' groups intended to collaborate in doing the action research on a formal and contractual basis.

f. Group members keep a beef cattle quantity of more than 30 head in a group animal pen.

g. Group members own productive palm oil plantation at an age of around 10 years.

h. Selected cattlemen have a commitment to work together in following the procedures of action research.

i. Groups have potential human resources members that can be a research counterpart, due to their essential role in maintaining the work continuity.

\section{Selected location and farmers groups}

Based on the potential groups' short list from both districts, a site visit was made to four groups in Dharmasraya.

a. Farmer group 'Amanah', at Sitiung B Aksen, Sitiung sub-district.

b. Farmer group 'Sri Langgeng', at Tabek village, in Timpeh sub-district.

c. Farmer goup 'Alam Sari', Koto Tinggi vilage, at Koto Besar sub-district.

d. Farmer group 'Eksekutif Mandiri', Siguntur village, at Sitiung sub-district.

Then in Pasaman Barat the district collaborative team has visited two groups:

a. Farmer group 'Tanjung Keramat', Bandua Balai sub-village, at Kinali village, Kinali sub-district.

b. Farmer group 'Karya Muda', Langgam sub-village, Kinali, at Kinali sub-district.

On the basis of aforementioned principles, the collaborative team chose 'Sri Langgeng', as the research site in Dharmasraya. While its location is quite far from transportation access, the group members were keen to adopt cattle reproduction and feed supplement technology as well as organic fertilizer.

In Pasaman Barat, the group Tanjung Keramat, at Bandua Balai sub-village, Kinali was selected. Its location is far enough from the district municipality, but is closer to the district border with Agam district. They were also keen to adopt cattle reproduction and feed supplement technology as well as organic fertilizer.

\section{Socio-economic data of the group}

A socio-economic survey was conducted at each group to gain baseline data on the pre-treatment context. Following the treatment a further socio-economic was conducted to asses the effect the treatment. The survey was conducted as follows;

a. A semi-structured questionaire was prepared before visiting the group members. Thirteen farmers participated in Sri Langgeng and 10 farmers in Tanjung Keramat.

b. Group members gathered together at a cattle pen location to complete a semi-structured questionaire.

c. Each farmer worked alone to complete the questionaire, but when he faced difficulties, a member of the team would help to explain the objective of the question.

d. One of the collaborative team members conducted an in-depth interview with the group chairman to gain a comprehensive group profile.

e. Atfter completing the semi-structured questionaire, there was a discussion on planning and implementing the next activity. 
Table 2. Result of Baseline Data on Socio-Economic Condition of the Respondents.

\begin{tabular}{llcc}
\hline No & \multicolumn{1}{c}{ Parameter } & $\begin{array}{c}\text { Sri Langgeng, } \\
\text { Dharmasraya }\end{array}$ & $\begin{array}{c}\text { Tanjung Keramat. } \\
\text { Pasaman Barat }\end{array}$ \\
\hline 1. Number of respondents (head) & 13 & 10 \\
2. & Average age (year) & 43,4 & 39,0 \\
3. Formal Education (year) & 9,3 & 8,8 \\
4. Number of family members (head) & 4,6 & 4,4 \\
5. & Palm Plantation (ha) & 4,1 & 2,2 \\
6. Number of Cattle (head) & 6,2 & 4,2 \\
7. Monthly income (Rp. 1,000) & 1.650 & 1.600 \\
8. Monthly income from keeping cattle & 1.708 & 0.393 \\
& (Rp. 1,000) & & \\
\hline
\end{tabular}

Socio-economic conditions before intervention are shown in Table 2.

Culturally, there was a significant disconnection between two selected groups in both districts. Members of Sri Langgeng (SL) group in Dharmasraya come from transmigrants of a Javannese and Sundanes ethnicity as well as some of West Sumatrans. Members of Tanjung Keramat (TK) group from Pasaman Barat district are entirely Minangkabau from West Sumatra.

SL group members have been settled in the location for a long time. They are farming families that have successfuly survived since the last 20 years despite a shortage of facilities at the first settlement location. The introduction of a palm oil plantation to the transmigrant settlement has accelerated their improved quality of life.

TK group has relatively recently been introduced to the palm oil plantation compared to SL as well as the husbandry of their beef cattle. Then there was a significant between SL and TK in term of palm oil plantation size ( $4.1 \mathrm{vs} 2.2 \mathrm{ha}$ ) and number of cattle ownership (6.2 vs 2.2 per head). Whilst average TK member was lower in palm oil plantation size and cattle owrnership, SL has a less job variations as well as expertise than TK.

All the 23 respondents were men with average 39 years old. SL members were older than TK for 9 years. Both TK and SL members are in the age of a productive living period which is compatible with the accelerated adoption of innovation.

Generally, respondents had been formally educated until the secondary school level ( 8.8 years), with SL members being slightly higher. The formal education level tended to be categorized as technical work compared to administrative tasks. Thus, there was a need to focus on the administrative improvement to increase group performance by collaborative supervision.

Integrated farming is the mainstream job of the respondents. Although, palm oil plantation was the general occupation, there were various other professions among the farmers, such as; producing rice, rubber, corn, and raising animals. Therefore, the existance of animal-crop integration has been found as a starting point to carry out action research.

The average number of family members was 4.5 , reflecting the respondents have small household associated with family planning program. Yes, it was close to the motto of 'two children are enough' due to two other family members are their parents. Again, SL was higher than TK, while in the future may be different because the younger members of TK group may increase their family size.

The farmers incomes could be divided into two methods of accounting; i) the respondent filled alone their monthly income (Rp 1.65 million SL vs Rp1.6 million TK), and ii) the member of the collaborative team counted respondents income from raising beef cattle. The result showed that SL group had a higher monthly income than TK (Rp 1.707 million SL vs Rp 0.393 million TK). Thus, the contribution of keeping cattle income was four times at SL compared to TK, although its number of cattle comparison was only $3: 2$. 
Research on palm oil by-products for cattle.

Feeding palm oil by-products.

At an early stage, cattle were given fresh grass while introducing palm oil by-products. Then, cattle were trained and adapted to palm oil by-products in a silage form consisting of palm oil fronds $(60 \%)$, PKC (25\%), molasses (10\%), and rice bran (5\%). These mixed feeds were kept in vacuum plastic containers in silage form in order to reduce feed processing time to be done once in a week.

An initial $2 \mathrm{~kg}$ of palm oil fronds was given, which was subsequently increased to $3 \mathrm{~kg} / \mathrm{head} / \mathrm{day}$. Native grass was continuously offered by farmers at $25 \mathrm{~kg} / \mathrm{head} /$ day to the cattle.

The Bali cattle were chosen to be the research objects with 19 head and 25 head of mature cattle at SL and TK respectively. The composition of feed is shown in Table 3. The estimate composition of rations, feed nutrient and materials price is shown in Table 4. Table 4 also showed that the feed composition reached the daily cattle requirement as indicated by crude protein and total digestible nutrient (TDN).

Table 3. Number of Cattle and Feed Amount at Each Group

\begin{tabular}{lcccc}
\hline \multirow{2}{*}{ Indicators } & \multicolumn{2}{c}{ Sri Langgeng } & \multicolumn{2}{c}{ Tanjung Keramat *) } \\
\cline { 2 - 5 } & Control & $\begin{array}{c}\text { Feed } \\
\text { supplement }\end{array}$ & Control & $\begin{array}{c}\text { Feed } \\
\text { supplement }\end{array}$ \\
\hline 1. Number of cattle (head) & 10 & 9 & 11 & 14 \\
2. Feeding Amount: & 25 & 25 & 25 & 25 \\
Fresh grass (kg/head/day) & - & 3 & - & 3 \\
Palm oil by-products (kg/head/day) & & & & \\
\hline
\end{tabular}

*) Solid in West Pasaman was not available due to palm oil processing shortage.

\section{Animal growth.}

Cattle were weighted three times for TK group and twice for the SL. Cattle body weight and average daily gained can be seen in Table 5, showing that TK was higher than SL. There was a fluctuation of body weight change during the research period, due to the dry season and difficulties in collecting enough fresh grass as well as a number of pregnant cows calving result in a significant body weight losses. However, in general cattle with feed supplementation showed an increasing body weight.

In contrast, controlled animals have decreased their body weight of -0.17 and $-0.11 \mathrm{~kg} / \mathrm{head} / \mathrm{day}$ respectively. As shown in Table 5, there was an indication that body weight increased due to addition of palm oil by-products with a cumulative growth of 0.14 and $0.09 \mathrm{~kg} / \mathrm{head} /$ day respectively. Animal growth during the research period can be seen in Figure 1 and Figure 2.

Table 4. Composition of Rations, Feed Nutrient and Tentative Feed Price.

\begin{tabular}{lccccccc}
\hline Feed Composition & $\begin{array}{c}\text { Dry } \\
\text { matter } \\
\text { portion } \\
(\%)\end{array}$ & $\begin{array}{c}\text { Dry } \\
\text { matter } \\
\text { content } \\
(\%)\end{array}$ & $\begin{array}{c}\text { Crude } \\
\text { protein } \\
(\%)\end{array}$ & $\begin{array}{c}\text { Crude } \\
\text { fibre } \\
(\%)\end{array}$ & $\begin{array}{c}\text { TDN } \\
(\%)\end{array}$ & $\begin{array}{c}\text { Ash } \\
(\%)\end{array}$ & $\begin{array}{c}\text { Price } \\
(\mathrm{Rp} / \mathrm{kg})\end{array}$ \\
\hline Rice bran & 2 & 90 & 6.7 & 23.9 & 58.42 & 12.5 & 2,500 \\
Palm oil fronds & 15 & 50.0 & 3.1 & 36.7 & 47.2 & 2.4 & 300 \\
PKC & 2 & 94.9 & 14.5 & 15.3 & 87.2 & 3.2 & 2,500 \\
Molases & 1 & 77.0 & 5.4 & 10.0 & 54.0 & 10.4 & 4,000 \\
Fres grass & 80 & 20,0 & 10,7 & 28,4 & 53,7 & 13,7 & 100 \\
Average fresh feed/kg & - & 28,0 & 8,8 & 28,6 & 57,6 & 9,5 & - \\
Cattle requirement & - & - & 8,0 & 22,0 & 58,0 & $<10$ & - \\
Silage price/kg - & - & - & - & - & - & - & 1.255 \\
Price of fresh grass/day & - & - & - & - & - & - & 2.500 \\
\hline
\end{tabular}


Table 5. The Average Body Weight and Daily Gain.

\begin{tabular}{|c|c|c|c|c|c|}
\hline \multirow{2}{*}{ Group } & \multicolumn{4}{|c|}{ Bodyweight (kg/head) } & \multirow{2}{*}{$\begin{array}{c}\text { Cumulative ADG } \\
\text { (gr/ekor/hr) }\end{array}$} \\
\hline & $\mathrm{I}$ & II & III & IV & \\
\hline \multicolumn{6}{|l|}{ Sri Langgeng } \\
\hline Control ( 9 head) & 221.1 & 189 & 198.6 & 205.8 & -170 \\
\hline Feed supplement (average 10 head) & 205.9 & 209.9 & 202.4 & 218 & 135 \\
\hline \multicolumn{6}{|l|}{ Tanjung Keramat } \\
\hline Control ( 11 head) & 213.4 & 201.8 & 202,2 & 203.9 & -105 \\
\hline Feed supplement (average 14 head) & 246.4 & 259.3 & 255.8 & 254.2 & 90 \\
\hline
\end{tabular}

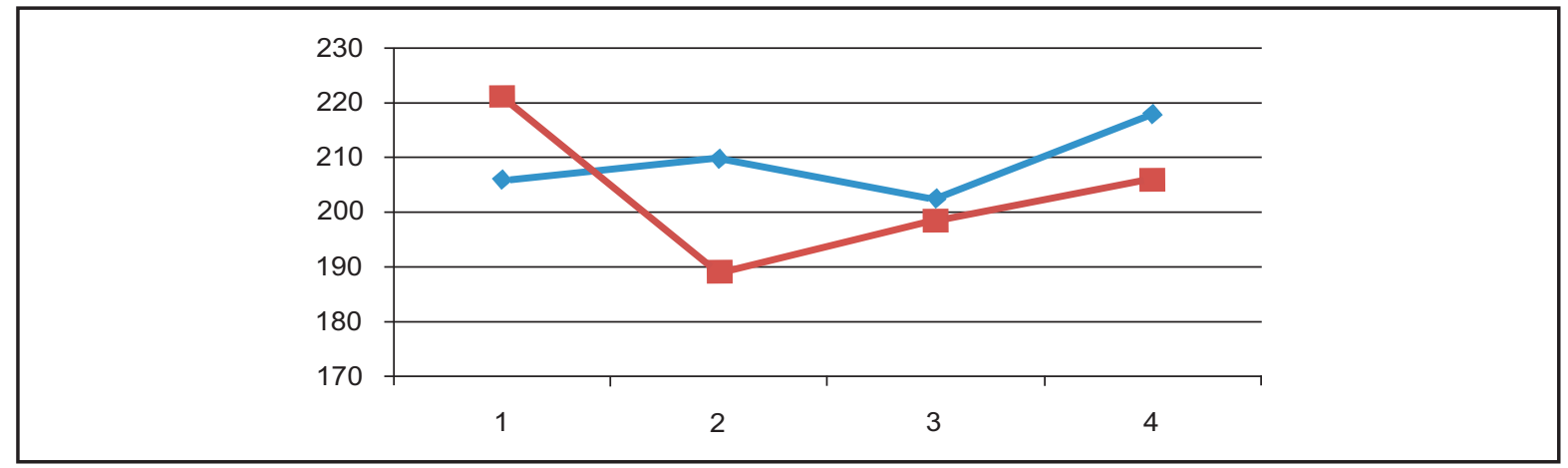

Figure 1. The Cattle Bodyweights changes at Sri Langgeng Farmers Group.

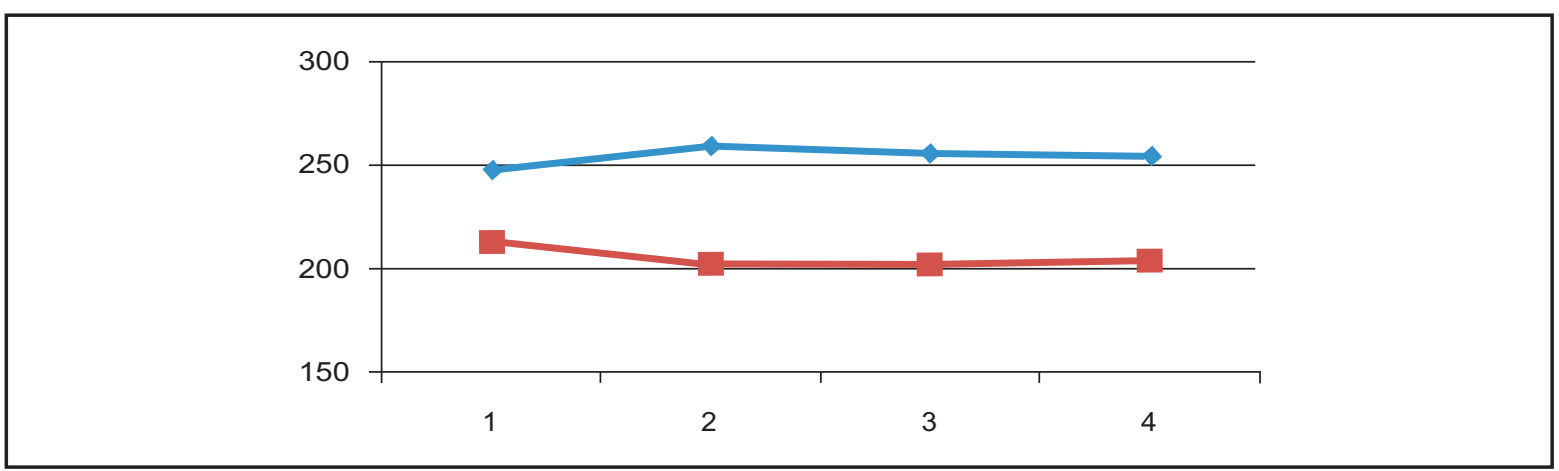

Figure 2. The Cattle Bodyweights changes at Tanjung Keramat Farmers Group.

\section{Organic Fertilizer Usage}

In order to evaluate the effect of organic fertilizer on palm oil fruits, the research series also involved using productive palm oil with the following treatments;

a. Palm oil trees fertilized with inorganic fertilizer as normally recommended dosage for eight trees.

b. Palm oil trees fertilized with both the inorganic and organic fertilizer $(50 \mathrm{~kg} /$ tree $)$ for eight palm oil trees.

c. Palm oil trees fertilized with only organic fertilizer $(50 \mathrm{~kg} / \mathrm{tree})$ for eight trees.

The last treatment (number c) was specially proposed by farmers participated in the research to identify the effect of organic fertilizer only without any inorganic fertilizer. This idea was a positive contribution to the collaborative team.

The results of trials lasting from August to November 2014 are shown in Table 6. Both providing organic fertilizer and inorganic fertilizer increased palm fruits production by $39.4 \%$ at Sri Langgeng farmers group and $48.4 \%$ at Tanjung Keramat farmer group respectively. This result could be associated to land condition at each location. 
Table 6. Palm Oil Fruit Production with Chemical, Organic and Combined Fertilizers (kg).

\begin{tabular}{lcccc}
\hline \multicolumn{1}{c}{ Location } & Number of Trees & Inorganic & Organic & Inorg+Organic \\
\hline Sri Langgeng & 8 & 43.6 & 36.3 & 60.8 \\
Tanjung Keramat & 8 & 43.8 & 48.6 & 65 \\
Sri Langgeng & $135 / \mathrm{ha}$ & 730 & 405 & 950 \\
Tanjung Keramat & $135 / \mathrm{ha}$ & 740 & 820 & 1,096 \\
\hline
\end{tabular}

Providing the organic fertilizer only without inorganic fertilizer just decreased palm fruits at Sri Langgeng (-16.7\%) farmers group. In contrast, the similar treatment resulted in an increasing fruit production at Tanjung Keramat $(11.0 \%)$. Figure 3 shows the effect of providing organic fertilizer to palm fruit production.

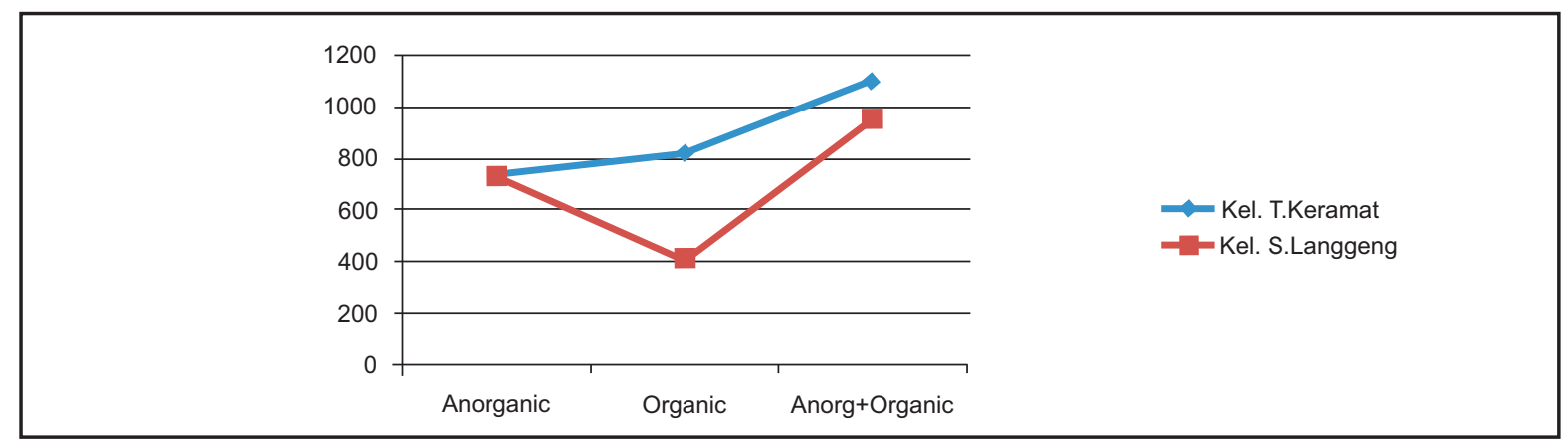

Figure 3. Effect of Providing Organic Fertilizer to Palm Oil Fruits Production (kg/ha).

In general, there was a positive result of providing organic fertilizer in order to increase palm oil fruit production. Similar research at another location (Sitiung site) also showed the increasing trend of palm oil fruit production (Bamualim et al, 2013).

Field Meeting and Result Discussion

At the end of the research series, there was a field meeting to socialize the results among the palm oil plantation farmers in Sri Langgeng group. Participants came from a number of groups as well as local agricultural extension officers to disseminate the results at a wider level. The occasion was held on November 2014 with 60 participants.

\section{CONCLUSIONS}

The results of the research activities could be concluded as follows;

a. Socio-economic evaluation showed that the Tanjung Keramat farmers group is behind Sri Langgeng in the introduction of both palm oil plantation and raising beef cattle program. In fact, both palm oil plantation and number of cattle own (4.1 vs $2.2 \mathrm{ha}$ ) and (6.2 vs $2.2 \mathrm{head}$ ) was smaller at farmers group of Tanjung Keramat (TK) than Sri Langgeng (SL).

b. There was an effect of providing feed supplement on the palm oil by-products basis to increase the cattle production as indicated by increasing $\mathrm{ADG}$ at the rate of $0.45 \mathrm{~kg} / \mathrm{head} / \mathrm{day}$ and 0.26 $\mathrm{kg} / \mathrm{h}$ ead/day respectively. In contrast, the control treatment experienced a decrease of daily body weight by $-0.51 \mathrm{~kg} / \mathrm{head} /$ day and $-0.31 \mathrm{~kg} / \mathrm{head} /$ day respectively.

c. The production of palm oil fruits increased from both the chemical fertilizer and organic fertilizer treatments by $39-48 \%$. However, the usage of organic fertilizer only showed a different trend in both farmers groups; an increasing by $11 \%$ at TK and decreasing by $-16,6 \%$ at SL.

d. It is recommended that utilization of palm oil by-products as a potential feed for beef cattle should be always disseminated to stakeholders of palm oil plantation in West Sumatra Province. 


\section{ACKNOWLEDGMENTS}

The authors acknowledged the Agency of Agricultural Research and Development through KKP3SL activity which supported the action research. Appreciation also goes to Animal Production and Veterinary Services of West Sumatra Province and both Dharmasraya and Pasaman Barat districts for coordination at selecting locations and farmers groups. Then, the participation of researchers at West Sumatra's Agricultural Technology Assessment Institute, to discuss technical aspects and problems faced in the field area.

\section{REFERENCES}

Azmi and Gunawan. 2005. Pemanfaatan pelepah kelapa sawit dan solid untuk pakan sapi potong. Proceeding of Animal Husbandry and Veterinary Technology. Centre for Animal Reserach and Development. Bogor.

Bamualim, A., Wirdahayati, and Marak Ali. 2006. Profile of Rising Cattle and Buffalos in West Sumatra. West Sumatra's Agricultural Research Center. Sukarami.

Bamualim, A. and B. Tiesnamurti. 2009. Konsepsi sistem integrasi antara tanaman padi, sawit dan kakao dengan ternak sapi di Indonesia. in "Sistem Integrasi Ternak Tanaman: Padi-Sawit-Kakao" page: 1-14. Center for Animal Research and Development of the Agricultural Department Research Center. Jakarta.

Bamualim, A., Wirdahayati, Y. Hendri, Ratna A.D., Jefrey M. Muis, Agusviwarman, Sadar and Aguswarman. 2013. Kajian Pengembangan Teknologi Pakan Sapi Berbasis Sawit Mendukung Integrasi Sapi-Sawit di KP Sitiung, Sumatera Barat. Final Report 2013. West Sumatra's Agricultural Research Center. Sukarami.

Bamualim, A., Wirdahayati, Ratna A.D., Jefrey M. Muis, and R. Wahyuni. 2012. Kajian percepatan pengembangan teknologi pakan sapi potong melalui pemanfaatan hasil ikutan tanaman sawit mendukung program gerakan pensejahteraan petani (GPP) di Sumatera Barat. National seminar on Establishing Center of Excellent to Develop the Animal Husbandry Industry for Self Sufficient in Meat Production. Mataram, 11 Desember 2012.

Buharman, B. 2011. Pemanfaatan teknologi pakan berbahan baku lokal mendukung pengembangan sapi potong di Provinsi Sumatera Barat. Wartazoa Vol 21, No.3:133-144.

Djajanegara, A., I.G. Ismail and S. Kartaatmaja. 2006. Teknologi dan manajemen usaha berbasis ekosistem. In "Integrasi Tanaman-Ternak di Indonesia" (Eds. E. Pasandaran, F. Kasryno dan A.M. Fagi). Page: 251-275. The Agricultural Department Research Center. Jakarta.

Edwardi, 2009. Program dan Kegiatan Dinas Peternakan Provinsi Sumatera Barat. Paper presented at Extension Services forum of West Sumatra. Padang.

Elisabeth, J and Simon P. Ginting. 2003. Pemanfaatan Hasil Samping Industri Kelapa Sawit Sebagai Bahan Pakan Ternak Sapi Potong. Workshop on the Animal - Crop Integration. Jakarta.

Hosen, N. 2006. Prospek Pengembangan Ternak Sapi Lokal di Sumatera Barat. Proceeding of National Seminar on Animal Husbandry. West Sumatra's Agricultural Research Center Padang; 11-12 September 2006.

Mathius, I-W., D. Sitompul, B.P. Manurung and Azmi. 2004. Produk samping tanaman dan pengolahan kelapa sawit sebagai bahan pakan ternak sapi potong: Suatu tinjauan. Proceeding national workhsop on the Animal - Crop Integration. Agricultural Department Research Center. Bengkulu provincial government and PT.Agricinal. Page; 120-128.

Puastuti, W. 2008. Optimasi Penggunaan Produk Samping Kelapa Sawit Sebagai Pakan Ruminansia. Proceeding on Optimalization of palm oil processing by-products to animal feed additive, page: 143-151. 